\title{
Termal Otel İşletmelerinde Örgütsel Stresin Örgüt Sağlığı Üzerindeki Etkisi (The Effect of Organizational Stress on Organizational Health in Thermal Hotels)
}

\section{Neslihan KAN SÖNMEZ iD a}

a Harran Üniversitesi, Birecik Meslek Yüksekokulu, Turizm ve Otel İşletmeciliği Programı, Şanlıurfa, 63420, Türkiye. neslihankan@harran.edu.tr

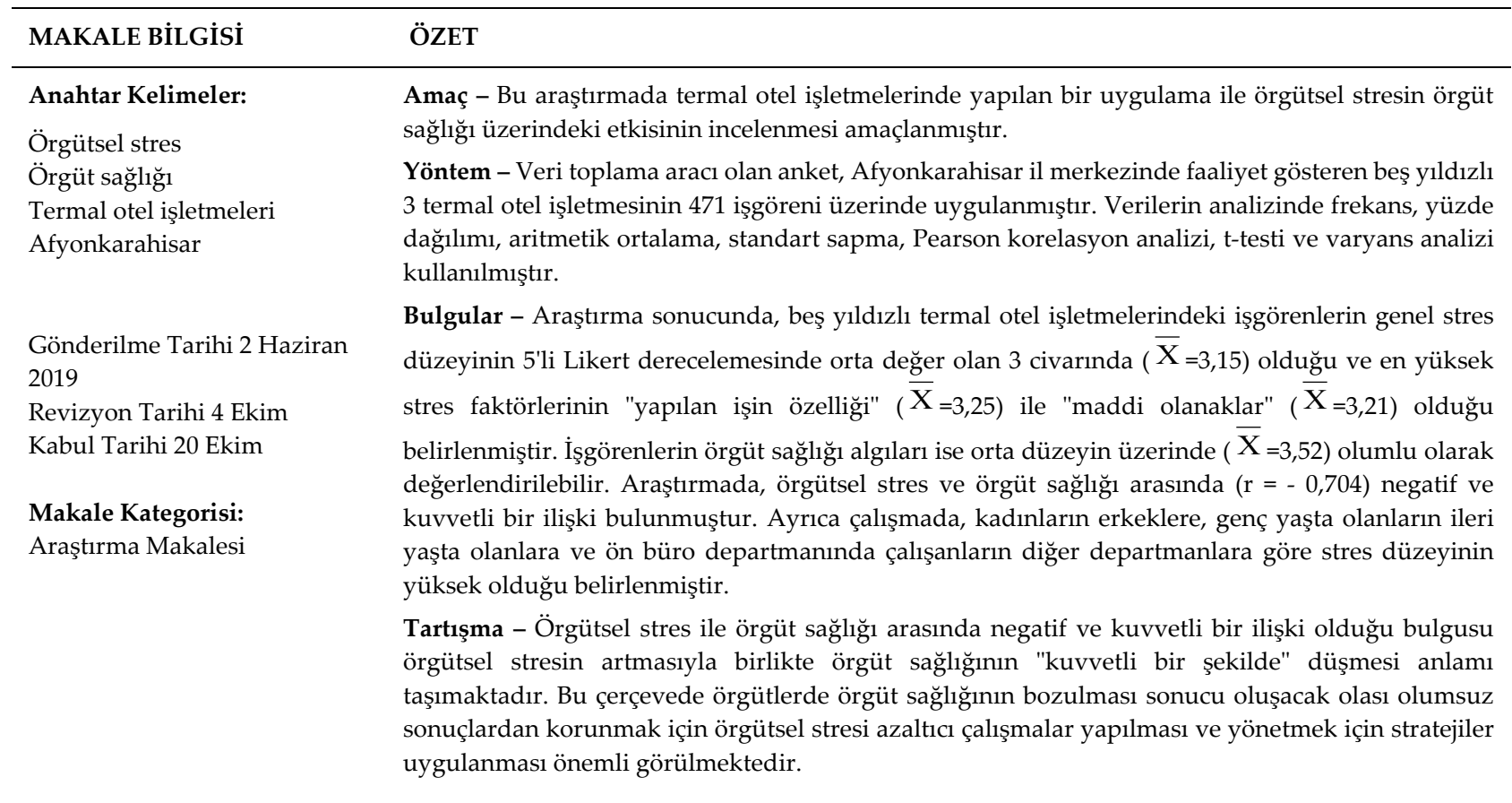

\begin{tabular}{|c|c|}
\hline ARTICLE INFO & ABSTRACT \\
\hline Keywords: & $\begin{array}{l}\text { Purpose - In this study, it was aimed to examine the effect of organizational stress on organizational } \\
\text { health with an application in thermal hotel enterprises. }\end{array}$ \\
\hline $\begin{array}{l}\text { Organizational health } \\
\text { Thermal hotels } \\
\text { Afyonkarahisar }\end{array}$ & $\begin{array}{l}\text { Design/methodology/approach - The study was carried out with the survey on } 471 \text { employees of } 3 \\
\text { thermal hotel enterprises operating in Afyonkarahisar. Frequency, percentage distribution, } \\
\text { arithmetic mean, standard deviation, Pearson correlation analysis, t-test and variance analysis were } \\
\text { used to analyze the data. }\end{array}$ \\
\hline $\begin{array}{l}\text { Received } 2 \text { June } \\
\text { Revised } 4 \text { October } \\
\text { Accepted } 20 \text { October }\end{array}$ & $\begin{array}{l}\text { Findings - In the study, it was found that the general stress level of employees in five-star thermal } \\
\text { hotel establishments was around } 3(\bar{X}=3,15) \text { in the 5-point Likert rating and the highest stress } \\
\text { factors were in "the feature of the job" }(\bar{X}=3,25) \text { and "financial possibility" }(\bar{X}=3,21) \text {. } \\
\text { Organizational health perceptions of employees were evaluated as positive and over medium level } \\
(\bar{X}=3,52) \text {. In the study, a negative and strong relationship was found between organizational stress }\end{array}$ \\
\hline $\begin{array}{l}\text { Article Classification: } \\
\text { Research Article }\end{array}$ & $\begin{array}{l}\text { and organizational health }(\mathrm{r}=-0,704) \text {. Besides it was determined that the stress level of women was } \\
\text { higher than men, young people had more stress level than old people and those working in front } \\
\text { office department had more stress level than employees in other departments. }\end{array}$ \\
\hline & $\begin{array}{l}\text { Discussion - The finding of "there is a negative and strong relationship between organizational } \\
\text { stress and organizational health" means that the organizational health decreases with the increase } \\
\text { of organizational stress. Within this framework, it is considered important to implement strategies } \\
\text { to reduce organizational stress in order to prevent the possible negative consequences of } \\
\text { organizational health deterioration in organizations. }\end{array}$ \\
\hline
\end{tabular}




\section{GİRIŞ}

Dinamik sosyal sorunlar nedeniyle günümüzde stres ciddi bir kavram olarak karşımıza çıkmaktadır. Bununla birlikte bireyler sadece sosyal sorun kaynaklı stresin etkileriyle yüzleşmekle kalmamakta, aynı zamanda örgütsel ortamda da benzer sıkıntılar yaşanmaktadır (Yousefi vd., 2016). Stres kavramı, tanınmış bir tıp uzmanı olan Selye'nin 1950'lerde psikolojik stres araştırmasına öncülük etmesiyle literatüre girmiş ve o tarihten bu yana sosyal bilimler araştırmalarında kullanılmıştır (Areekkuzhiyil, 2014). Magnuson (1990) stresi, bireyin gerçek dünyası ile beklentileri arasındaki farklılığa gösterdiği tepkisi olarak ifade ederken, Robbins (2001) bireyin arzu ettiği şeyle ilgili bir fırsat, kısıtlama veya talep ile karşı karşıya kaldığı ve sonucun hem belirsiz hem de önemli olarak algılandığı dinamik bir koşul olarak tanımlamaktadır.

Örgütsel stres iş, çalışma ortamı ve örgütsel iklimin agresif ve zararlı yönlerine duygusal, bilişsel, davranışsal ve fizyolojik bir cevap olarak ifade edilmektedir. Görevleri çözmede çaresizlik duyguları ile karakterize bir durumdur. Başka bir deyişle, işle ilgili stres, bazı talepler ile kendi yetenekleri veya bilgileri dışında olan özel görevlerle yüzleşmeleri gerektiğinde bireylerin tepkileridir (Bucurean ve Costin Madalina, 2011). Örgütsel stres birçok nedene bağlı olarak ortaya çıkar, ancak işgörenler yöneticilerden ve meslektaşlarından destek almadıklarını veya onların talep ve baskılarıyla nasıl başa çıabileceklerini bilmediklerini hissettiklerinde ve iş üzerinde çok az kontrol sahibi olduklarında durum genellikle daha da kötüleşir (Leka vd., 2003). Örgütsel stres, bir yandan işgörenlere yapılan talep ve baskılar, bir yandan da işgörenlerin bilgi ve yetenekleri arasındaki uyumsuzluktan kaynaklanmaktadır (Di Martino ve Musri, 2001). Bu durum işgörenlerin işle başa çıkma yeteneklerini zorlamaktadır. Bu, yalnızca iş baskılarının işgörenin üstesinden gelme yeteneğini aştı̆̆ı durumları değil aynı zamanda işgörenin bilgi ve yeteneklerinin yeterince kullanılmadığı ve bu onlar için bir problem olduğu durumları da içerir (Areekkuzhiyil, 2014).

Sağlıklı bir iş ortamında da işgörenlerin üzerinde belirli seviyede baskı hissedilmesi muhtemeldir. İşgörenlerin yetenekleri ve kaynakları üzerindeki kontrol miktarı ve kendileri için önemli olan kişilerden aldıkları destek bu aşamada belirleyici olmaktadır. Sağlık, sadece hastalık ya da halsizlik olmayışı değil, aynı zamanda fiziksel, zihinsel ve sosyal iyilik hali olduğundan (WHO, 1986), sağlıklı bir çalışma ortamı, yalnızca zararlı koşulların bulunmadığı değil, örgüt sağlığını teşvik eden yararlı koşulların olduğu bir durumdur. Yararlı koşullar, örgüt sağlığını tehdit eden risklerin sürekli değerlendirilmesini, örgüt sağlığı konularında gerekli bilgi ve eğitimin sağlanmasını ve sağlığı teşvik eden örgütsel destek uygulamaları ve yapılarının varlığını içerebilir. Sağlıklı bir çalışma ortamı, çalışanların bireysel sağlığını ve örgüt sağlığını geliştirmeyi öncelikli kabul ettiği ve çalışma yaşamlarının bir parçası haline getirdiği ortamdır (Leka vd., 2003).

En stresli iş türü, işgörenlerin bilgi ve yetenekleriyle eşleşmeyen, aşırı talep ve baskılara değer veren, herhangi bir seçim ya da kontrolü uygulamak için çok az fırsat bulunan ve başkalarından çok az destek alanlardır. Örgütsel ortamda işin talepleri ve baskıları ne kadar fazla olursa olsun, iş işgörenlerin bilgi ve yetenekleri ile eşleşirse, örgütsel stres yaşama olasıllı̆̆ o kadar düşüktür. İşgörenler örgütsel ortamda veya işle ilgili olarak diğerlerinden ne kadar çok destek alırlarsa, örgütsel stres yaşama olasıllğı o kadar düşüktür. İşgörenler ne kadar çok çalışmalarını ve çalışma tarzlarını kontrol ederlerse ve işlerini ilgilendiren kararlara ne kadar katılırlarsa, örgütsel stres yaşama ihtimalleri o kadar düşüktür.

Örgütsel stresin nedenlerinin çoğu, işin tasarlanma şekli ve örgütlerin yönetilme şekli ile ilgilidir. Bu yönler zarar verme potansiyeline sahip olduğundan, "strese bağlı tehlikeler" olarak adlandırılır. Strese ilişkin literatür genel olarak dokuz strese bağlı tehlike kategorisini tanır ve bunlar Tablo 1'de listelenmiştir. Bununla birlikte, bu tehlikelerin bazılarını evrensel olamayabileceğini veya belirli kültürlerde zararlı olarak kabul edilemeyebileceğini unutmamak gerekir.

Tablo 1. Örgütsel Strese Bağll Tehlikeler

\begin{tabular}{lll}
\hline İş İçeriği & İş Yükü ve İş temposu & Çalışma saatleri \\
• Monoton, az teşvik edici, & $\bullet$ Görevin çok az veya çok & $\bullet$ Sıkı ve esnek olmayan çalışma \\
anlamsız görevler & fazla olması & programları \\
• Çeşitlilik eksikliği & $\bullet$ Zaman baskısı altında & $\bullet$ Uzun ve sosyal olmayan saatler \\
- Hoş olmayan görevler & çalışma & $\bullet$ Tahmin edilemez çalışma saatleri \\
- Zorlayıcı görevler & & $\bullet$ Kötü tasarlanmış vardiya sistemleri
\end{tabular}




\begin{tabular}{|c|c|c|}
\hline $\begin{array}{l}\text { Katılım ve Kontrol } \\
\text { - Karar vermede katılım } \\
\text { eksikliği } \\
\text { • Kontrol eksikliği (örneğin, } \\
\text { çalışma yöntemleri } \\
\text { üzerinden, } \\
\text { çalışma temposu, çalışma } \\
\text { saatleri ve çalışma ortamı) }\end{array}$ & $\begin{array}{l}\text { Kariyer Gelişimi, Statüsü ve } \\
\text { Ücreti } \\
\text { • İş güvensizliği } \\
\text { • Promosyon olanaklarının } \\
\text { eksikliği } \\
\text { • Düşük tanıtım veya aşırı } \\
\text { tanıtım } \\
\text { • “Düşük sosyal değer” } \\
\text { çalışması } \\
\text { • Belirsiz veya haksız } \\
\text { performans değerlendirme } \\
\text { sistemleri } \\
\text { • İş için fazla yetenekli veya az } \\
\text { yetenekli olma }\end{array}$ & $\begin{array}{l}\text { Örgütlenmedeki Rolü } \\
\text { - Belirsiz rol } \\
\text { - Aynı iş içindeki çatışma rolleri } \\
\text { - İnsanlara karşı sorumluluk } \\
\text { - Sürekli olarak diğer insanlarla } \\
\text { yaşanılan sorunlar }\end{array}$ \\
\hline $\begin{array}{l}\text { Kişilerarası ilişkiler } \\
\text { - Yetersiz, düşüncesiz veya } \\
\text { desteksiz nezaret } \\
\text { - İş arkadaşlarıyla zayıf } \\
\text { ilişkiler } \\
\text { - Zorbalık, taciz ve şiddet } \\
\text { - İzole veya yalnız çalışma } \\
\text { - Sorunlarla baş etmek için } \\
\text { mutabık kalınan } \\
\text { prosedürlerin yokluğu veya } \\
\text { şikayetler }\end{array}$ & $\begin{array}{l}\text { Organizasyon kültürü } \\
\text { - Zayıf iletişim } \\
\text { - Kötü liderlik } \\
\text { - Örgütsel hedefler konusunda } \\
\text { netlik eksikliği }\end{array}$ & $\begin{array}{l}\text { Ev İş Arayüzü } \\
\text { • İş ve ev talepleriyle çelişme } \\
\text { • İşyerinde ev içi sorunlara destek } \\
\text { eksikliği } \\
\text { • Evde iş sorunları için destek eksikliği }\end{array}$ \\
\hline
\end{tabular}

Kaynak: Leka, S., Griffiths, A., Cox, T. and World Health Organization. (2003). Work Organization and Stress: Systematic Problem Approaches for Employers, Manages and Trade Union Representatives, Occupational and Environmental Health Team, Geneva, 6-7.

Strese ilişkin literatür incelendiğinde birçok araştırmacının örgütsel ortamda iş hayatının birçok yönünü stres ile ilişkilendirdiği görülmektedir. Öncelikle işin kendisinin özellikleri stresli olabilir, yani iş yükü (DeFrank ve Ivancevich, 1998; Sparks ve Cooper, 1999) güç eksikliği, rol belirsizliği ve rol çatışması (Nelson ve Burke, 2000) örgütlerde stres kaynağıdır. İşyerindeki sosyal çevrenin kalitesi, liderin belli davranışları olduğu gibi stres ile ilişkilidir (Sparks ve Cooper, 1999, Carlopio vd., 1997; Cooper ve Marshall, 1976). Fazlalık tehdidi, değer düşüklüğü ve net olmayan tanıtım umutları dahil olmak üzere kariyer gelişimi ve başarısına yönelik tehditler streslidir (Nelson ve Burke, 2000). Ev ile iş arasındaki çatışma ve kişisel ilişkilerde işin etkisi streslidir (Sparks ve Cooper, 1999). Ayrıca, yüksek gürültü seviyeleri, işyerinde aşırı kalabalık veya mahremiyet eksikliği gibi fiziksel koşullar stres ile ilişkilendirilmiştir (Burke, 1988; akt: Areekkuzhiyil, 2014).

Turizm sektörü, karakteristik özellikleri açısından stresin yüksek olduğu bir iş ortamında düşük ücret imkanı sunan, uzun çalışma saatlerine sahip, işgören moralinin düşük ve iş-aile çatışma olasılığının yüksek olduğu bir sektördür (Şahin, 2007). Turizm sektöründe işgören devir hızının yüksek olması işgücü maliyetinin yükselmesine, işgücü verimliliği, iş tatmini ve hizmet kalitesinin düşmesine neden olmaktadır (Şahin, 2007). Bunu etkileyen önemli faktörlerden birisi de örgütsel strestir. Görüldüğ̈̈ üzere örgütsel stres turizm sektöründe de diğer sektörlerin çoğunda olduğu gibi örgütsel yaşamın bir gerçeğidir. Rekabet, değişim ve belirsizliğin olduğu çalışma ortamına sahip olan turizm sektöründe çalışanlar stres yaratan faktörlerin çoğunu kontrol edememekte ve bu ortama uyum sağlamakta zorlanmaktadırlar. Dış koşulların baskısıyla şekillenen plan ve programlarını yürütme sürecinde çalışanlar, büyük stres altında kalmaktadırlar (Uzun ve Yiğit, 2011).

Yukarıdaki bilgiler ışığında stresin diğer sektörlerin çoğunda olduğu gibi turizm sektöründe de hem bireysel anlamda hem de dolaylı olarak örgütler açısından farklı olumsuz sonuçlar doğuracağını söylemek mümkündür. Bu bağlamda örgüt sağlığı da örgütsel stresten etkilenebilecek önemli bir kavram olarak karşımıza çıkmaktadır. 


\section{N. Kan Sönmez 11/4 (2019) 2442-2455}

İşletme yönetimi literatüründe, iş etiği, iş tatmini, örgüt kültürü, örgütsel bağlllık ve örgütsel stres vb. kavramların üzerinde durulmuş, ancak "örgüt sağlığı" kavramına gereken önem verilmemiştir. Bu durum örgüt sağlığının bilinen ve kabul gören bir kavram olmasını engellemiştir (Lyden ve Klingele, 2000). Zaman içerisinde araştırmacılar ve teorisyenler örgütleri açı sistemler olarak ele alıp, örgütsel etkinlik kriterlerini belirlemeye yoğunlaştıkça kavram gelişmiştir (Zamora, 2016). Son zamanlarda "örgüt sağlığı" kavramı, sıklıkla kullanılan ve geniş çapta onaylanmış bir yaklaşım haline gelmiştir (Kant, 2017).

Örgüt sağlığı kavramı, ilk olarak 1969 yılında okulların örgüt sağlığı analizinde Miles tarafından kullanılmıştır. Miles, okulların örgüt sağlığı için bir model önermiş ve sağlıklı bir örgütlenmeyi şu ifadelerle tanımlamıştır: "Sağlıklı bir örgüt, mevcut ortamında durağan olmayan, kendisini idare etme ve devam etme becerisini geliştirebilen örgüttür" (Miles, 1969). Miles (1969) sağlıklı bir sistemi, oldukça dayanıklı sistem özelliklerine sahip açık bir sosyal sistemin çerçevesi olarak ele almıştır. İlgili literatürde kabul gören bir başka tanıma göre ise örgüt sağlığı örgütü çevreye adapte edebilme, üyeleri arasında uyum oluşturma ve hedeflerine ulaşma becerisi olarak ifade edilmiştir (Hoy ve Tarter, 1997; Hoy ve Miskel, 1991). Bu nedenle örgüt sağlığının, işgörenlere elverişli ve liberal bir ortam sağladığı koşullar olduğu açıktır (Kant, 2017). Sauter vd.'ne göre (1996) ise sağllklı bir örgüt refah için işgören hedeflerinin ve karlılık ile verimlilik için örgüt hedeflerinin entegrasyonunu maksimize eden bir kuruluştur. Bu tanımdaki ikili odak, bir örgüt içinde neyin sağllk oluşturduğu fikrindeki bir değişimi temsil eder. Geleneksel olarak, bir örgütün sağllğı, sağlığı optimize etmek yerine, zayıf sağlıktan kaçınma hedefiyle değerlendirilmiştir. Günümüzde örgüt sağlığı için yol gösterici ilkeler, bireyler ve iş ortamı arasında meydana gelen sürekli bir işlem sürecine odaklanan multidisipliner bir bakış açısıyla yansıtılmaktadır. İşyerinde refah, sağlığın örgütsel risklerden ve uygulamaların teşvik edilmesinden nasıl etkilendiğini anlamayı gerektirir (Grawitch vd., 2006). Örgütlerde örgüt sağlı̆̆ını oluşturan şey, görünüşte yalnızca işyerinde potansiyel olarak zararlı faktörlerle değil aynı zamanda işverenlerin işgörenlerin ihtiyaçlarını anlama ve faaliyetleri teşvik etme konusundaki çıkarlarıyla da ilgilidir (Cox ve Leiter, 1992).

Sağlıklı bir örgüt, genel itibariyle insanların çalışmayı sevdikleri ve bu örgütün bir parçası olmaktan gurur duydukları yerdir (Pordeli ve Vazifeh, 2017). Genel anlamda sağlıklı bir örgütün bazı karakteristik özellikleri göstermesi beklenir. İlk olarak kurumsal hedeflerin ve kişisel hedeflerin entegrasyonu sağlanmalıdır. Sosyoteknik sistemin taleplerine göre en uygun örgüt yapısı oluşturulmalıdır. Örgütün işgörenlerin katılımını destekleyen demokratik bir işleyişi olmalıdır. Adaletli insan kaynakları yönetimi ve istihdam ilişkileri politikaları uygulanmalıdır. Örgütte farklı seviyeleri arasında karşılıklı güven ve desteğin sağlanması, birey ve örgüt arasındaki psikolojik sözleşmenin kabulünün sağlanması, işgörenlerin ihtiyaç ve beklentilerinin, bireysel farklılıkların ve niteliklerini tanınması gereklidir. Olumlu tanınmaya dayanan adil ödül sistemleri uygulanmalıdır. Kişisel gelişim ve kariyer ilerlemesi için fırsatlar sunulmalıdır. Örgütle özdeşlik ve sadakat duygusu oluşturulmalıdır. Bunların yanısıra iş hayatının kalitesi için çaba gösterilmesi, gereksiz çatışmalardan kaçınılması ve yönetsel davranış ve belirli iş durumuna uygun liderlik tarzlarının sergilenmesi sağlıklı bir örgüt yapısı için gerekli olan diğer özelliklerdir (Nyakora, 2016).

Bir örgütün sağlığının ölçülmesi, bir ailenin sağlığının ölçülmesinden daha kolay değildir. Örgüt sağlıklı olduğunda, problemler sadece motive edicidir. Ancak, örgüt sağlıksız olduğunda sorunlar ağır basar, örgütün işleyişini ciddi oranda etkiler. Örgüt sağlığı koşullarını anlamak, sadece çalışma koşulları ve dinamikleri açısından önemli değil, aynı zamanda örgütsel etkinlik, işgörenlerin performansının iyileştirilmesi, örgütsel bağlılık, çalışanların insani eğilimleri ve karşılıklı güvenleri için de öngörücüdür. Örgüt sağlığı boyutlarının ve göstergelerin kuruluşlardaki varlığı örgütsel çevreyi iyileştirir. Bu niteliksel ve niceliksel gelişme kapsamlı büyüme ve gelişme sağlayabilir. Örgüt sağlığı konusunda yapılan araştırmalar, yetkin yöneticilerin seçilmesine ve istihdam edilmesine yardımcı olabilir. Örgüt sağlı̆̆ı hakkında bilgi edinerek, yönetsel güçlü ve zayıf yanların yanı sıra entelektüel ve fiziksel yeteneklerin de örgütsel olayları ustalıkla idare edebileceği bilinmektedir. Örgütsel durumu yeniden yapılandırmak ve iyileştirmek için örgüt sağlığının boyutları bilinmeli ve iyileştirilmelidir (Bahramian ve Saeidian, 2013).

Miles (1969) çalışmasında sağlıklı örgütlere ilişkin on boyut belirlemiştir. Diğer araştırmacılar tarafından yaygın bir şekilde referans gösterilen bu boyutlar hedef odağ 1 (goal focused), iletişim yeterliliği (comunication adequacy), optimal güç denkleştirme (optimal power equalization), kaynak kullanımı (resource utilization), yanaşıklık (cohesiveness), moral (morale), yenilikçilik (innovation), özerklik (autonomy), uyum sağlama (adaptations), ve problem çözme yeterliliği (problem solving adequecy)'dir. Hoy vd., (1990) bu boyutları 
açıklamıştır. Hedef odağ1 işgörenlerin örgütün amaç ve hedeflerini açık ve güvenilir kabul etmesi, desteklemesi ve savunmasıdır. İletişim yeterliliği örgüt içerisinde hem dikey hem de yatay bilgi akışı ve paylaşımının olmasıdır. Optimal güç denkleştirme örgüt içerisinde üst ve astların etkileşim içerisinde olması ve örgüte zarar vermeyecek nitelikte rekabet yaşamasıdır. Kaynak kullanımı örgütün tüm kaynaklarını özellikle işgücünü etkin bir şekilde koordine etmesi ve sürekliliğini sağlamasıdır. Yanaşıklık üyelerin örgüte hayranlık ve bağlılık duymasıdır. Moral üyelerin örgüt içerisinde kendilerini güvende ve mutlu hissetmeleri, yüksek iş doyumu yaşamalarıdır. Yenilikçilik örgütte üyelerin yaratıcllık yeteneği ve inovatif düşüncelerinin desteklenmesidir. Özerklik örgütün kendi kendini özgürce yönetebilmesi, dış değişikliklere karşı bağımsız hareket edebilmesidir. Uyum sağlama örgütün gelişim ve büyüme için yaşadığ 1 değişim sürecinde stresi tolere edebilmesi ve istikrarı koruyabilmesidir. Problem çözme yeterliliği örgütün sorunları algılama ve bunları minimum enerji ile çözme yeteneğine sahip olmasıdır.

Örgüt sağlığının Lyden ve Klingele (2000) perspektifinden boyutları ise, iletişim, katılım, sadakat ve bağlılık, moral, kurumsal itibar, etik performansın tanınması, amaç birliği, liderlik, gelişim ve kaynak kullanımı olmak üzere on bir boyutu içermektedir. İletişim örgüt içerisinde iki yönlü ve güçlü bir iletişim ağının olmasıdır. Katılım üyelerin işle ilgili alınan kararlara, işleyiş süreçlerine ve sonucun denetimine katılmasıdır. Sadakat ve bağlılık üyelerin örgüte güven ve hayranlık duymasıdır. Moral üyelerin bireysel ve örgütsel amaçların başarılmasına karşı gösterdiği mesleki ilgi ve isteğin yüksek olmasıdır. Kurumsal itibar örgütün dış paydaşlarının örgüt hakkındaki algısının olumlu olmasıdır. Etik örgüt üyelerinin gerçekleştirdiği tüm faaliyetlerde dürüstlük, güven, saygı ve hakça davranmayı ilke edinmesi, hiçbir alanda politik davranmamasıdır. Performansın tanınması örgütün üyelerin bireysel potansiyellerini keşfetmesini desteklemesi ve onları cesaretlendirmesidir. Amaç birliği bireysel rol ve amaçlarla, takım rol ve amaçlar arasındaki ilişkinin net olmasıdır. Liderlik liderlerin üst düzey yöneticilerle, kendi seviyelerindeki yöneticilerle ve astlarıyla iyi ilişkiler içinde olmasıdır. Gelişim eğitim ve gelişim programlarına, örgütün iç ve dış çevreleri tarafından desteğin fazla olmasıdır. Kaynak kullanımı örgütte kaynakların başarı beklentileriyle tutarlı şekilde paylaşılmasıdır.

$\mathrm{Bu}$ araştırmada termal otel işletmelerinde yapılan bir uygulama ile örgütsel stresin örgüt sağllğ 1 üzerindeki etkisinin incelenmesi amaçlanmıştır. Bu temel amaca göre araştırmanın hipotezi aşağıdaki gibi ifade edilebilir:

Hipotez: Otel işletmelerinde örgütsel stresin örgüt sağllğı üzerinde anlamlı ve negatif bir etkisi vardır.

Araştırma kapsamında yapılan literatür incelemesinde turizm alanına yönelik bu iki değişken arasındaki ilişkiyi inceleyen herhangi bir araştırmaya rastlanmamıştır. Bundan dolayı çalışmanın söz konusu boşluğu doldurması beklenmektedir. Ayrıca araştırmanın ilgili literatüre katkı sunacağı gibi yalnız otel işletmeleri değil tüm işletmeler için yol gösterici bir kaynak olabileceği değerlendirilmektedir.

\section{YÖNTEM}

Betimsel bir araştırma özelliğinde olan bu araştırmada veriler anket tekniği ile toplanmıştır. Söz konusu anket 3 temel bölümden oluşmaktadır. İlk bölümde otel işletmesi işgörenlerinin bazı bireysel özelliklerini (cinsiyet, yaş, eğitim, departman, çalışma süresi) belirlemeye yönelik sorulara yer verilirken, ikinci bölümde işgörenlerin örgütsel stres düzeylerini belirlemek amacıyla Eren-Gümüştekin ve Öztemiz (2004) tarafından farklı kaynaklardan yararlanarak oluşturulan ve 28 madde ile 5 boyutu (yapılan işin özelliği, yönetici, mesleki ilerleme, maddi olanaklar ve iş arkadaşları ile ilgili stres kaynakları) içeren ölçeğe yer verilmiştir. Anketin üçüncü bölümünde ise beş yıldızlı termal otel işletmelerinin örgüt sağlığı düzeylerini belirlemeye yönelik Lyden ve Klingele (2000) tarafından geliştirilen ve Güllü (2018) tarafından Türkçe geçerlik ve güvenirlik çalışması yapılan 20 maddeden oluşan ölçek kullanılmıştır. Ölçeğin orjinali 11 alt boyuttan oluşmakla birlikte Güllü (2018) tarafından yapılan Türkçe geçerlik ve güvenirlik çalışması sonucunda ölçeğin genel olarak toplam varyansın \%65,003'ünü açıklayan "Amaç Birliği, İtibar ve Gelişim" ile "İletişim, Moral ve Performans" olmak üzere 2 boyuttan oluştuğu belirtilmiştir. Ölçeklerde yer alan her bir madde beşli Likert derecelendirilmesine tabi tutulmuştur ve " $1=$ Hiç Katılmıyorum", "2=Az Katılıyorum", "3=Orta Düzeyde Katılıyorum", " $4=$ Çok Katılıyorum", "5=Tamamen Katıllyorum" olarak kodlanmış ve değerlendirmeler 5 üzerinden yapılmıştır.

$\mathrm{Bu}$ araştırmanın evreni, Afyon il merkezinde faaliyet gösteren beş yıldızlı termal otel işletmelerinin işgörenlerinden oluşmaktadır. Araştırmada otel işletmeleri beş yıldızlı olmaları sebebiyle homojen olarak 
varsayılmış ve her biri bir küme olarak ele alınarak küme örnekleme yöntemi ile örneklem alınma yoluna gidilmiştir. Bu çerçevede uygulamayı kabul eden 9 adet beş yıldızlı otel işletmesi içerisinden 3 adet otel işletmesi tesadüfi yöntemle (kura ile) belirlenmiş ve anket uygulaması 2018 Eylül-Ekim ayları içerisinde gerçekleştirilmiştir. Örneklem büyüklüğünün hesaplanmasında Özdamar (2001) tarafından önerilen $\mathrm{n}=\mathrm{s}^{2} \mathrm{Z} \alpha^{2} / \mathrm{d}^{2}$ formülü dikkate alınmış ve 40 kişilik pilot uygulama yapılmıştır. Bu doğrultuda anlamlılık düzeyi $\alpha=0,05$ için $Z 0,05=1,96$, standart sapma $s=1$ ve örneklem hatası $d=0,1$ olarak belirlenmiş olup en düşük örneklem büyüklüğü 385 olarak hesaplanmıştır. Buna göre yaklaşık 600 adet anket çoğaltırmış ve 200 'er adet 3 otele dağıtılmıştır. Hatalı, yanlış, eksik, yanlı ve güvenirliği düşük anketler dikkate alındığında geri dönen 558 anketten 471 'i değerlendirmeye layık bulunmuştur.

Çalışmada otel işletmesi işgörenlerinin bireysel özellikleri için sıklık ve yüzde dağılımları kullanılmıştır. Diğer taraftan ölçek ve alt ölçekler (alt boyutlar) için aritmetik ortalama ve standart sapma değerleri hesaplanmıştır. Ölçek ve alt boyutları arasındaki ilişkiler Pearson korelasyon analizi ile belirlenmiştir. Bununla birlikte, işgörenlerin örgütsel stres ve örgüt sağllğına ilişkin görüşlerinin demografik özelliklere göre karşılaştırılmasında (parametrik test varsayımları sağlandığı için) $t$ testi ve tek yönlü varyans analizi uygulanmıştır. Diğer taraftan, ölçeklerin yapı geçerliliği için açıklayıcı faktör analizi uygulanmış ve ayrıca güvenirlik analizine ilişkin iç tutarlığı Cronbach's Alpha katsayıları ile hesaplanmıştır. Verilerin analizinde SPSS for Windows istatistik programı kullanılmıştır.

\section{BULGULAR}

Katılımcıların bireysel özelliklerine göre dağılımı Tablo 2'de verilmiş olup; \%39,7'si kadın, \%60,3'ü erkek ve $\% 27,2$ 'si 29 yaş ve altı, \%55,4'ü 30-39 arası, \%17,4'ü 40 yaş ve üzerindedir. İşgörenlerin \%22,6'sı lisans ve lisansüstü eğitime sahipken \%38,2'si lise ve önlisans mezunudurlar. Katılımcıların \%18,7'sinin önbüro, \%46,3'ünün yiyecek içecek, \%28'inin insan kaynakları, Satış-Pazarlama, Muhasebe ve \%7'sinin de diğer departmanlarda görev yaptıkları belirlenmiştir.

Tablo 2. Katılımcıların bazı bireysel özelliklerine göre dağılımı

\begin{tabular}{llrr}
\hline Değişken & Grup & Sayı (f) & Yüzde (\%) \\
\hline Cinsiyet & Kadın & 187 & 39,7 \\
& Erkek & 284 & 60,3 \\
Yaş & 29 ve altı & 128 & 27,2 \\
& $30-39$ & 261 & 55,4 \\
& $40-49$ & 63 & 13,4 \\
& 50 ve üzeri & 19 & 4,0 \\
Eğitim & İköğretim ve altı & 185 & 39,3 \\
& Lise-Önlisans & 180 & 38,2 \\
& Lisans & 61 & 13,0 \\
& Lisansüstü & 45 & 9,6 \\
Departman & 88 & 18,7 \\
& Önbüro & 218 & 46,3 \\
& Yiyecek İçecek & 132 & 28,0 \\
& İnsan Kay., Satış-Pazarlama, Muh. & 33 & 7,0 \\
& Diğer (Kat Hiz., Teknik Serv. vb). & 471 & $\mathbf{1 0 0 , 0}$ \\
\hline
\end{tabular}

Örgütsel stres ve örgüt sağlığı ölçeklerinin yapı geçerliğine yönelik uygulanan faktör analizleri ve güvenirlik analizine ilişkin Cronbach's Alpha katsayıları ile ölçek ve alt boyutlarına ait bazı betimsel istatistikler Tablo 3 'te verilmiştir. Faktör analizinin uygulanabileceğini ve örneklem büyüklügünün yeterli düzeyde olduğunu Bartlett's testi ve KMO değerleri (Örgütsel Stres Ölçeği için $\mathrm{KMO}=0,826$; Bartlett's Testi: $\chi 2=1642,5$; $\mathrm{P}<0,001$; Örgüt Sağlığ 1 Ölçeği için KMO=0,819; Bartlett's Testi: $\chi 2=1977,9 ; \mathrm{P}<0,001)$ göstermektedir. Faktör analizi sonuçlarına göre örgütsel stres ölçeği toplam varyansın 67,122'sini açıklayan 5 faktör altında toplanırken, örgüt sağlığı ölçeği ise Güllü (2018) tarafından yapılan Türkçe geçerlik ve güvenirlik çalışmasına benzer 
şekilde toplam varyansın 62,283'ünü açılayan 2 faktör altında toplanmıştır. Bununla birlikte Cronbach's Alpha değerleri örgütsel stres ölçeği için $\alpha=0,788$ ve örgüt sağllğ ölçeği için 0,809 olarak hesaplanmıştır.

Alt boyutlara ilişkin hesaplanan Cronbach's Alpha değerleri de 0,70 değerinin üzerinde bulunmuş olup bu değerler ölçek ve alt ölçeklerin iç tutarlıklarının yüksek olduğunu göstermektedir. Tablo 3 'teki alt boyutlara ilişkin aritmetik ortalama değerleri incelendiğinde, beş yıldızlı termal otel işletmelerindeki işgörenlerin genel stres düzeyinin 5'li Likert derecelemesinde orta değer olan 3'e yakın olmakla birlikte orta düzeyin az da olsa üzerinde olduğu $(\bar{X}=3,15)$ tespit edilmiştir. Bununla birlikte, en yüksek stres faktörleri "yapılan işin özelliği ( $\bar{X}=3,25)$ ile "maddi olanaklar" ( $\bar{X}=3,21$ ) olurken, en düşük stres faktörü ise "mesleki ilerleme" ( $\bar{X}=3,03)$ boyutu olmuştur. Örgüt sağllğ̆ ölçeği için hesaplanan aritmetik genel ortalama değeri $(\bar{X}=3,52)$ olarak hesaplanmış olup, bu değer otel işletmelerindeki işgörenlerin örgüt sağlı̆̆ı algılarının çok yüksek olmasa da ortanın üzerinde olumlu olduğunu göstermektedir. Ölçeğin birinci faktörü olan "Amaç Birliği, İtibar ve Gelişim" alt boyutunda hesaplanan ortalama $(\overline{\mathrm{X}}=3,61)$, "İletişim, Moral ve Performans" alt boyutu için hesaplanan ortalamadan $(\overline{\mathrm{X}}=3,44)$ yüksek bulunmuştur.

Tablo 3. Örgütsel stres ve örgüt sağlığı ölçeklerinin geçerlik güvenirlik sonuçları ve bazı betimsel istatistikler

\begin{tabular}{|c|c|c|c|c|c|c|}
\hline Ölçek / Alt boyutlar(Faktörler) & 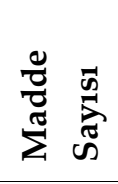 & 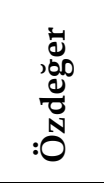 & 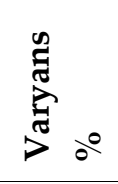 & 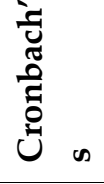 & $\bar{X}$ & SS \\
\hline Yapılan işin özelliği (Faktör 1) & 6 & 8,235 & 27,567 & 0,785 & 3,25 & 0,87 \\
\hline Maddi olanaklar (Faktör 2) & 6 & 5,344 & 17,889 & 0,798 & 3,21 & 0,89 \\
\hline Mesleki ilerleme (Faktör 3) & 5 & 3,232 & 10,819 & 0,759 & 3,03 & 0,91 \\
\hline Yönetici (Faktör 4) & 5 & 2,021 & 6,765 & 0,792 & 3,11 & 0,77 \\
\hline İş arkadaşları (Faktör 5) & 6 & 1,219 & 4,081 & 0,754 & 3,12 & 0,78 \\
\hline Örgütsel Stres Ölçeği (Genel) & 28 & - & 67,122 & 0,788 & 3,15 & 0,71 \\
\hline Amaç Birliği, İtibar ve Gelişim (Faktör 1) & 9 & 8,121 & 37,345 & 0,765 & 3,61 & 0,87 \\
\hline İletişim, Moral ve Performans (Faktör 2) & 11 & 5,423 & 24,938 & 0,792 & 3,44 & 0,75 \\
\hline Örgüt Sağlığı Ölçeği (Genel) & 20 & - & 62,283 & 0,809 & 3,52 & 0,68 \\
\hline
\end{tabular}

Örgütsel Stres Ölçeği: Kaiser-Meyer-Olkin (KMO) $=0,826 ;$ Bartlett's Testi: $\chi^{2}=1642,5 ; P<0,001$

Örgüt Sağll̆ğ Ölçeği için: Kaiser-Meyer-Olkin( KMO)=0,819; Bartlett's Testi: $\chi^{2}=1977,9 ; P<0,001$

Örgütsel stres ve örgüt sağlığı arasındaki ilişkiye yönelik uygulanan Pearson korelasyon analizi sonuçları Tablo 4'te sunulmuştur. Bulgular, ölçekler ve alt boyutlarına ait değişkenler arasındaki ilişkilerin hepsinin negatif ve anlamlı $(p<0,01)$ olduğunu göstermiştir. Korelasyon katsayıları incelendiğinde örgütsel stres ve örgüt sağllğ 1 arasında $(r=-0,704)$ negatif ve kuvvetli $(0,60<r<0,80)$ bir ilişki bulunmuştur. Bu durum, örgütsel stresin artmasıyla birlikte örgüt sağlığının "kuvvetli bir şekilde" düşmesi anlamı taşımaktadır. Bununla birlikte örgütsel stres, örgüt sağlığının "İletişim, Moral ve Performans" (r=-0,685) alt boyutu ile "Amaç Birliği, İtibar ve Gelişim" ( $r=-0,637)$ alt boyutuna göre daha fazla negatif ilişki içerisindedir. Diğer korelasyon katsayılarına göre genel olarak örgüt sağlığı ile en çok ilişkisi olan örgütsel stres alt boyutunun "mesleki ilerleme" $(\mathrm{r}=-0,702)$ olduğu ve bunu "maddi olanaklar" ( $\mathrm{r}=-0,603)$, "yapılan işin özelliği" ( $\mathrm{r}=-0,598)$, "yönetici" $(\mathrm{r}=-0,589)$ ve "iş arkadaşları" (r=-0,534) boyutlarının izlediği görülmektedir. 
Tablo 4. Örgütsel stres ve örgüt sağlığı arasındaki ilişkiye yönelik korelasyon katsayıları

\begin{tabular}{lccc}
\hline Ölçek/Alt Boyutlar & $\begin{array}{c}\text { Amaç Birliği, } \\
\text { İtibar ve } \\
\text { Gelişim }\end{array}$ & $\begin{array}{c}\text { İletişim, Moral } \\
\text { ve Performans }\end{array}$ & $\begin{array}{c}\text { Örgüt Sağlı̆̆ı Ölçeği } \\
\text { (Genel) }\end{array}$ \\
\hline Yapılan işin özelliği & $-0,512^{* *}$ & $-0,565^{* *}$ & $-0,598^{* * *}$ \\
Maddi olanaklar & $-0,525^{* *}$ & $-0,587^{* *}$ & $-0,603^{* * *}$ \\
Mesleki ilerleme & $-0,612^{* *}$ & $-0,647^{* *}$ & $-0,702^{* *}$ \\
Yönetici & $-0,514^{* *}$ & $-0,533^{* *}$ & $-0,589^{* *}$ \\
İşarkadaşları & $-0,422^{* *}$ & $-0,514^{* *}$ & $-0,534^{* *}$ \\
Örgütsel Stres Ölçeği (Genel) & $-0,637^{* *}$ & $-0,685^{* *}$ & $-0,704^{* *}$ \\
\hline${ }^{* *} p<0,01$ & & &
\end{tabular}

Katılımcıların örgütsel stres ve örgüt sağlığına ilişkin görüşleri bireysel özelliklerine göre karşılaştırılmış olup farklılık bulunan değişkenlere ilişkin t-testi ve varyans analizi sonuçları Tablo 5 'te sunulmuştur. Buna göre örgütsel stres düzeyi cinsiyet, yaş ve departmana göre anlamlı farklılık gösterirken $(p<0,05)$, örgüt sağllğı ise sadece cinsiyete göre anlamlı farklılık göstermektedir $(p<0,05)$. Gruplara ilişkin ortalama değerleri incelendiğinde, kadınların $(\overline{\mathrm{X}}=3,24)$, erkeklere $(\overline{\mathrm{X}}=3,00)$ göre örgütsel stres düzeylerinin daha yüksek olduğu, bununla birlikte örgüt sağlığı algılarının $(\bar{X}=3,42)$, erkeklere $(\bar{X}=3,60)$ göre daha düşük olduğu görülmektedir. Diğer taraftan yaş ilerledikçe örgütsel stres düzeyinin düştügü belirlenirken, stres düzeyinin en yüksek olduğu departmanın da ön büro olduğu tespit edilmiştir.

Tablo 5: Örgütsel stres ve örgüt sağlığına ilişkin katılımcı görüşlerinin bazı bireysel özelliklere göre karşılaştırılması

\begin{tabular}{|c|c|c|c|c|c|c|c|}
\hline \multirow{2}{*}{ Değişken } & \multirow{2}{*}{ Grup } & \multicolumn{3}{|c|}{ Örgütsel Stres } & \multicolumn{3}{|c|}{ Örgüt Sağlığı } \\
\hline & & $\bar{X}$ & SS & $\mathrm{p}$ & $\overline{\mathrm{X}}$ & SS & p \\
\hline \multirow[t]{2}{*}{ Cinsiyet } & Kadın & 3,24 & 0,65 & \multirow[t]{2}{*}{$0,001^{*}$} & 3,42 & 0,64 & \multirow[t]{2}{*}{$0,001^{*}$} \\
\hline & Erkek & 3,00 & 0,63 & & 3,60 & 0,60 & \\
\hline \multirow[t]{4}{*}{ Yaş } & 29 ve altı & 3,34 & 0,65 & \multirow{4}{*}{$0,038^{*}$} & 3,52 & 0,56 & \multirow{4}{*}{0,628} \\
\hline & $30-39$ & 3,20 & 0,66 & & 3,51 & 0,57 & \\
\hline & $40-49$ & 3,10 & 0,62 & & 3,49 & 0,51 & \\
\hline & 50 ve üzeri & 2,87 & 0,70 & & 3,59 & 0,46 & \\
\hline \multirow[t]{4}{*}{ Departman } & Önbüro & 3,37 & 0,56 & \multirow[t]{4}{*}{$0,008^{*}$} & 3,42 & 0,56 & \multirow[t]{4}{*}{0,122} \\
\hline & Yiyecek İçecek & 3,12 & 0,71 & & 3,51 & 0,53 & \\
\hline & İns. Kay.,Sat-Paz. & 3,07 & 0,63 & & 3,60 & 0,57 & \\
\hline & Diğer & 3,13 & 0,51 & & 3,51 & 0,61 & \\
\hline
\end{tabular}

${ }^{*} p<0,05$

\section{TARTIŞMA ve SONUÇ}

Dinamik sosyal sorunlar nedeniyle günümüzde stres ciddi bir kavram olarak karşımıza çıkmaktadır ve sadece bireyler stresten kaynaklanan bu semptomlarla yüzleşmekle kalmamakta, aynı zamanda örgütsel ortamda da benzer sıkıntılar yaşanmaktadır. Örgütsel ortamda stres, kabul edilemez seviyelere ulaştığında işgörenlerin psikolojik sağlığının bozulması neticesinde (Bhagat vd., 2010) azaltılmış verimlilik, azaltılmış inisiyatif, çalışmaya olan ilgi ve düşünce sertliği, örgüt ve meslektaşlar için endişe eksikliği, sorumluluk kaybı, ve fiziksel sağlı̆̆ın bozulması gibi bireysel sonuçlara yol açmaktadır (Greenberg ve Baron, 1995). Örgütsel boyutta ise iş tatmini, örgütsel bağlllık ve performansta bir düşüş, devamsızlıkta bir artış (Shi vd., 2013), gereksiz maliyetler yaratma (Goh vd., 2015; Hassard vd., 2017) gibi sonuçlara yol açmaktadır. Dolayısıyla, 


\section{N. Kan Sönmez 11/4 (2019) 2442-2455}

elde edilen tüm bu negatif sonuçların örgüt sağlığında da bir düşüşe neden olacağı düşünülmektedir. Yapılan birkaç araştırmada örgütsel ortamda yaşanan stresin örgüt sağlığında düşüşe neden olduğu sonucuna ulaşılmıştır (Fisher, 2001; Code ve Langan Fox, 2001; Chang vd., 2006; Gül, 2007). Bu bağlamda bu çalışmada, stresin yüksek olduğu iş ortamına sahip turizm sektöründe faaliyet gösteren termal otel işletmelerinde, örgütsel stresin örgüt sağlı̆̆ı üzerindeki etkisinin araştırılması amaçlanmıştır.

Turizm sektörünün fiziksel varlığının maldan çok, hizmet olması, emek yoğun üretim gerçekleştirmesi, temel sermayesinin insan gücü olması, turizm arzının sabit ya da kısıtlı olması, talebin ise çok duyarlı özellikle mevsimler itibariyle değişken olması, müşteri tatmini ve sadakatinin odağa alınması gibi nedenlerle turizm işletmelerinde stres yaşanma ihtimalinin yüksek olduğu söylenebilir. Bu çalışmada elde edilen sonuçlar, beş yıldızlı termal otel işletmelerinde genel stres düzeyinin orta düzeyin az da olsa üzerinde olduğunu ortaya koymuştur. Kılıç vd.'nin (2013) yapmış oldukları çalışmada ise termal otel işgörenlerinin örgütsel stres düzeylerinin orta seviyede olduğu belirlenmiştir. Benzer şekilde Yılmaz (2016) ve Arıkan (2011) tarafından otel işletmelerinde yapılan çalışmalarda da işgörenlerin stres düzeyinin orta olduğu sonucuna ulaşılmıştır. Tiyce vd.'de (2013) otel işletmeleri, kulüp ve casinolarda yaptıkları araştırma ile işgörenlerin çalışma ortamında genellikle stres altında olduğunu ortaya koymuşlardır. Chuang ve Lei (2011), Lo ve Lamn (2005), Pallesen'ın (2007) çalı̧̧maları ise otel işletmeleri işgörenlerinin iş stresi düzeylerinin ortalamalarının çok üstünde olduğunu göstermektedir.

Çalışmada, beş yıldızlı termal otel işletmelerinin işgörenlerinin örgüt sağlığı algılarının orta düzeyin üzerinde olduğu, bunun da olumlu olarak değerlendirilebileceği sonucuna ulaşılmıştır. Benzer şekilde Vural (2013) termal otel işletmelerinde gerçekleştirdiği araştırmada işgörenlerin örgüt sağlığına ilişkin algılarının pozitif yönde olduğunu tespit etmiştir. Doğan ve Bozkurt (2008) tarafından da 5 yıldızlı otel işletmesi yöneticilerinin ve çalışanlarının algıları aracılığıyla örgüt sağlığına ilişkin mevcut durumu incelenmiş ve genel örgüt sağlığı ortalamasının iyi olduğu belirtilmiştir. Kemer ve Aslan (2017) ise çalışmalarında konaklama işletmeleri işgörenlerinin çalıştıkları örgütleri orta düzeyde sağlıklı bulduklarını belirlemişlerdir.

Genel örgütsel stres ile genel örgüt sağlığı arasında negatif ve kuvvetli bir ilişki olduğu bulgusu da bu araştırmanın bir başka sonucudur. Bu durum, örgütsel stresin artmasıyla birlikte örgüt sağlığının "kuvvetli bir şekilde" düşmesi anlamı taşımaktadır. Ayrıca, örgütsel stres ve alt boyutları ile örgüt sağlığı ve alt boyutları arasındaki ilişkilerin hepsi negatif ve anlamlıdır. Daha açık bir ifade ile bu araştırmada, değişkenler arasında bulunan korelasyonlar örgütsel stresin örgüt sağlığı üzerindeki değişimi anlamlı olarak açıkladığını göstermiştir. Literatürde farklı sektörlerde yapılan birkaç araştırmada örgütsel ortamda yaşanan stresin örgüt sağlığında düşüşe neden olduğu sonucuna ulaşılmakla birlikte (Fisher, 2001; Code ve Langan Fox, 2001; Chang vd., 2006; Gül, 2007) turizm alanında doğruda bu iki değişkeni birlikte ele alan araştırmaya rastlanmamıştır. Bununla birlikte, literatürde örgütsel stres ve örgüt sağlığını etkileyen faktörleri ele alan çok sayıda araştırma mevcuttur. Arıkan (2011) beş yıldızlı otel işletmelerinde; Tuğal vd. (2017) seyahat acentalarında görev yapan işgörenler üzerinde yürüttükleri çalışmalarda örgüt sağlığı ile iş tatmini arasında pozitif yönlü ve kuvvetli bir ilişki olduğunu tespit etmişlerdir. Sandıkçı vd.'nin (2015) çalışmasında termal konaklama işletmelerinde dönüştürücü liderlik davranışları ile örgüt sağllğı arasında, Suiçer (2016)'nın çalışmasında otel işletmelerinde otantik liderlik davranışları ile örgüt sağlığı arasında anlamlı bir ilişki olduğu belirlenmiş̧ir. Bununla birlikte Daskin (2013) otel işletmelerinde işgörenler üzerinde yaptığ çalışma sonucunda öz-yeterliliğin örgütsel stresi azalttığı, adam kayırmanın ise örgütsel stresi önemli derecede artırdığını, Chuang ve Lei (2011) casino otellerde çalışan şef aşçılardan örgütsel stres yaşayanların iş tatminlerinin azaldığını, Hwang vd. (2014) zincir otel işletmelerinde çalışan müdürlerin yaşadığı örgütsel stresin işten ayrılma niyetini pozitif yönde etkilediğini, Yirik vd. (2014) otel işletmelerinde işgörenlerin örgütsel stres düzeyi arttıkça mesleki tükenmişlik düzeyinin yükseldiğini, Kılıç vd. (2013) termal otel işgörenlerinin yaşadığı örgütsel stres ile örgütsel sessizlik arasında orta kuvvette pozitif bir ilişki olduğunu, Uzun ve Yiğit (2011) ise turizm sektöründe orta kademe yöneticilerin yaşadıkları örgütsel stresin örgüte bağlllıklarını negatif yönde etkilediğini tespit etmişlerdir.

Bu araştırmada, örgüt sağlığı ile en yüksek ilişkili örgütsel stres boyutları sırasıyla "yapılan işin özelliği" ve "maddi olanaklar" olarak belirlenmiştir. Otel işletmelerinde işgörenlerin yaptıkları işin özelliğinin en önemli stres kaynağı olarak belirlenmesi işgörenlerin yaptıkları işi bilgi ve yetenekleriyle eşleşmeyen, aşırı talep ve baskılara değer veren, herhangi bir seçim ya da kontrolü uygulamak için çok az firsat bulunan ve başkalarından çok az destek alan bir iş olarak algıladığı şeklinde yorumlanabilir. Otel işletmelerinde yapılan 
iş işgörenlerin bilgi ve yetenekleri ile eşleşirse, işgörenler örgütsel ortamda veya işle ilgili olarak diğerlerinden ne kadar çok destek alırlarsa, ne kadar çok çalışmalarını ve çalışma tarzlarını kontrol ederlerse ve işlerini ilgilendiren kararlara ne kadar katılırlarsa, örgütsel stres yaşama ihtimalleri o kadar düşük olacaktır. İlgili literatürde araştırma bulgumuza benzer şekilde otel çalışanlarında strese neden olan en önemli etmenler arasında Demiray'ın (2015) ve Hu ve Cheng'in (2010) çalışmalarında yapılan işin özelliği, Hwang vd.'nin (2013) çalışmasında maaş oranı, Kılıç vd.'nin (2013) çalışmasında maddi olanaklar belirlenmiştir. Deveci'nin (2017) çalışmasında da düşük ücret ve belirsiz terfi beklentisi, Akova ve Işık'ın (2008) çalışmasında ise iş yerinde gelişme ve terfi imkanının az olması, maaş ve ödemelerin azlığı otel çalışanlarında stres nedeni olarak ortaya konulmuştur. Yapılan araştırmadan farklı olarak otel çalışanlarında strese neden olan en önemli etmenler arasında Wan (2013) rol belirsizliği, aşırı iş yükünü; Tiyce vd. (2013) personelin çalışma şartları, iş güvensizliğini; Hwang vd. (2014) ise fazla iş yükü sorumluluğu, haksız ve belli olmayan terfiyi saptamışlardır.

Bu çalışmada, kadınların erkeklere, genç yaşta olanların ileri yaşta olanlara ve ön büro departmanında çalışanların diğer departmanlara göre stres düzeyinin yüksek olduğu belirlenmiştir. Elde edilen bu sonuçlar değerlendirildiğinde kadın çalışanların iş hayatında daha fazla engelle karşılaşmaları onların örgütsel stres düzeylerini artırabilmektedir. Yaşları oldukça genç, muhtemelen iş hayatına yeni başlayan çalışanların örgütsel stres düzeylerinin daha ileri yaştaki çalışanlardan daha yüksek olmasının otel işletmesine uyum sorunuyla ilgili olduğunu, tecrübeyle birlikte işletmeye alışıkça örgütsel stres düzeylerinin azalacağını söylemek mümkündür. Ayrıca daha genç çalışanların aşırı beklentilere sahip olmaları ve kendilerine sunulandan daha fazlasına ulaşma isteğinde olmaları işe ilk girdiklerinde doyumsuzluk yaşamalarına, örgütsel stres düzeylerinin yüksek olmasına neden olabilmektedir. İlgili literatürde demografik özelliklerin belirleyici rolüne ilişkin elde edilen diğer sonuçlara bakıldığında Sökmen (2005) tarafından 4-5 yıldızlı otel işletmelerindeki yöneticiler üzerinde yapılan araştırmada erkek yöneticilerin kadın yöneticilere göre daha yüksek oranda stres altında kaldıkları belirlenmiştir. Yirik vd. 'nin (2014) çalışmasında ise 4-5 yıldızlı otel işletmelerinde 13 yıldan fazla çalışanlarda yüksek düzeyde örgütsel stres görülmüştür. Batı (2016) yiyecekiçecek işletmelerine yönelik yaptığı araştırmasında ise düşük eğitimli ve gelirli işgörenler ile mesleki deneyimi az olan işgörenlerin daha az stresli oldukları sonucuna ulaşmıştır. Chuang ve Lei (2011) casino otellerde çalışan şef aşçılardan çalışma süresi 5-10 yıl olan ve haftada 60 saat çalışan, lisans mezunu ve gece vardiyasında çalışan mutfak şeflerinin en yüksek seviye iş stresi yaşadıklarını ortaya koymuşlardır.

Çalışmada, işgörenlerin örgüt sağlığı algıları sadece cinsiyete göre anlamlı farklılık göstermiş ve erkeklerin kadınlara göre daha olumlu bir yaklaşım içerisinde oldukları tespit edilmiştir. Elde edilen bu sonuç kadın ve erkek çalışanların örgütsel faktörlerden eşit ölçüde etkilenmediğinin ve örgüt sağlığını benzer şekilde algılamadığının bir göstergesi olarak ifade edilebilir. Vural'ın (2013) termal konaklama işletmelerinde gerçekleştirdiği araştırmasında ise işgörenlerin örgüt sağlı̆̆ı algıları yaş, eğitim durumu ve çalışma süresine göre anlamlı bir farklılık gösterirken cinsiyet, medeni durum, çalışılan pozisyon grupları ve çalıştıkları bölüme göre örgüt sağlığı algısının değişmediği sonucuna ulaşılmıştır. Doğan ve Bozkurt (2008) tarafından 5 yıldızlı otel işletmelerinde yapılan araştırmada da işgörenlerin eğitim durumlarına, departmanlarına ve pozisyonlarına göre örgüt sağlığı algılarının değiştiğini sadece kıdeme göre anlamlı bir farklılık olmadığını tespit edilmiştir.

$\mathrm{Bu}$ araştırmada elde edilen sonuçlara kapsamında; örgütlerde örgüt sağlığının bozulması sonucu oluşacak olası olumsuz sonuçlardan korunmak için örgütsel stresi azaltıcı çalışmalar yapılması ve örgütsel stresi yönetmek için stratejiler uygulanması önerilebilir. Örneğin stres yaratabilecek işle ilgili sorunların erken önlenmesi ve ortadan kaldırılması, iş taleplerinin değiştirilmesi, işgörenlerin işlerini etkili bir şekilde yerine getirebilmek için gerekli bilgi ve becerilere sahip olmalarının sağlanması, işte kullanılan tekniğin sürekli iyileştirilmesi, işgörenlere stresin üstesinden gelmenin yollarını öğretmek için bir stres yönetimi eğitiminin sunulması, işgörenlerin ihtiyaç duyduğu desteğin artırılması bunlardan bazılarıdır. Bunların dışında uygun bir yönetim tarzının uygulaması, uygun bir çalışma ortamının sağlanması, işgörenler arasında iyi düzeyde bir işbirliğinin oluşturulması, disiplin prosedürlerinin açıkça tanımlanması, işgörenlerin örgüte bağlllık hissetmeleri ve amaçlarına ulaşmak için motive olmaları için destekleyici bir çalışma kültürünün oluşturulması, işgörenlere kariyerlerini geliştirmeleri için gerekli desteğin ve bilgilerin sunulması, esnek çalışma programlarının teşvik edilmesi, değişim sürecinin, işgörenlerin bu nedenle stres altında kalmayacağı şekilde yönetilmesi örgüt içerisindeki stresi azaltacak diğer stratejiler olarak önerilebilir. Diğer taraftan terfi ve maddi olanaklar çerçevesinde, otel işletmelerinde yükselme politikalarının adil olması, otel yöneticilerinin 
yeterli yetenek ve becerilere sahip tüm işgörenlere eşit fırsatlar sunması, ücret sisteminin işgörenin beklentisini karşılayacak düzeyde ve adil olduğuna inanılan bir sistem olması işgörenlerin stresle baş edebilmelerine destek sağlayabilecektir.

Bu çalışmada termal otel işletmelerinde örgütsel stresin örgüt sağllğ üzerindeki etkisi incelenmiş olup turizm alanına yönelik bu iki değişken arasındaki ilişkiyi inceleyen herhangi bir araştırmaya rastlanmamıştır. Dolayısıyla bu çalışmadan elde edilen sonuçların söz konusu eksikliği giderebileceği, hem örgütsel stres hem de örgüt sağlığ1 perspektifini genişleteceği ve ilgili literatüre önemli katkılar sunacağı düşünülmektedir.

\section{Kaynakça}

Akova, O. ve Işık, K. (2008). Otel İşletmelerinde Stres Yönetimi: İstanbul' daki Beş Yıldızlı Otel İşletmelerinde Bir Araştırma, Kocaeli Üniversitesi Sosyal Bilimler Enstitüsü Dergisi, 15(1), 17-44.

Areekkuzhiyil, S. (2014). Factors Influencing the Organizational Stress among Teachers Working in Higher Education Sector in Kerala: An Empirical Analysis, Research and Pedagogic Interventions, 2(2), 1-15.

Arıkan, E., (2011). Örgüt Sağlığının İş Tatmini Üzerine Etkisi: Afyonkarahisar'daki Beş Yıldızlı Otel İşletmelerinde Bir Uygulama, Yüksek Lisans Tezi, Afyon Kocatepe Üniversitesi, Sosyal Bilimler Enstitüsü.

Bahramian, A. and Saeidian, N. (2013), The Relationship between Organizational Health, Teachers' Organizational Commitment and their Perception of Elementary Schools Principals at Region 2, Esfahan in the Academic Year, European Online Journal of Natural and Social Sciences, 2(3), 2388-2396.

Batı, T. (2016). Örgütsel Güven ve Örgütsel Stres İlişkisi, Yüksek Lisans Tezi, Karabük Üniversitesi, Sosyal Bilimler Enstitüsü.

Bhagat, R. S., Krishnan, B., Nelson, T.A., Leonard, K.M., Ford, D.L. and Billing, T.K. (2010), Organizational Stress, Psychological Strain, and Work Outcomes in six National Contexts: A Closer Look at the Moderating Influences of Coping Styles and Decision Latitude, Cross Cultural Management: An International Journal,17(1), 10-29.

Bucurean, M. and Costin Madalina, A. (2011). Organizational Stress and Its Impact on Work Performance, Annals of Faculty of Economics, University of Oradea, Faculty of Economics, 1(7), 333-337.

Carlopio, J., Andrewartha, G. and Armstrong, H. (1997). Developing Management Skills in Australia MelbourneAsia Pacific, Journal of Human Resources, 36(2), 103-105.

Chang, E.M., Daly, J., Hancock, K.M., Bidewell, J.W., Johnson, A., Lambert, V.A. and Lambert, C.E. (2006) The Relationships Among Workplace Stressors, Coping Methods, Demographic Characteristics, and Health in Australian Nurses, Journal of Professional Nursing, 22(1), 30-38.

Chuang, N.K. and Lei, S. A. (2011). Job Stress among Casino Hotel Chefs in a Top-Tier Tourism City, Journal of Hospitality Marketing and Management, 20(5), 551-574.

Code, S. and Langan Fox, J. (2001). Motivation, Cognitions and Traits:Predicting Occupational Health, WellBeing and Performance, Stres and Health: Journal of the International Society for the Investigation of Stress, 17(3), 159-174.

Cooper, C. L. and Marshall, J. (1976). Occupational Sources of Stress: A Review of the Literature Relating to Coronary Heart Disease and Mental Ill Health, Journal of Occupational Psychology, 49(1), 11-28.

Cox, T. and Leiter, M. (1992). The Health of Health Care Organizations, Work and Stress, 6(3), 219-227.

Daskin, M. (2013). Favouritism and Self-Efficacy as Antecedents on Managers' Politics Perceptions and Job Stress, Anatolia, 24(3), 452-467.

DeFrank, R. and Ivancevich, J. (1998). Stress on the Job: An Executive Update, Academy of Management Executive, 12(3), 55-66.

Demiray, T., (2015). Örgütsel Stresin Örgütsel Sessizliğe Etkisi: Beş Yıldızlı Otel İşletmelerinde Bir Uygulama, Yüksek Lisans Tezi, Afyon Kocatepe Üniversitesi, Sosyal Bilimler Enstitüsü. 
Deveci, B. (2017). İş Stresi ve Turizm İşletmelerinde Yapılan Araştırmalara İlişkin Bir Değerlendirme, Mehmet Akif Ersoy Üniversitesi Sosyal Bilimler Enstitüsü Dergisi, 9(20), 39-53.

Di Martino, V. and Musri, M. (2001). Guidance for Prevention of Stress and Violence in the Workplace, Department of Occupational Safety and Health, Ministry of Human Resources, Malaysia.

Doğan, A. ve Bozkurt, S. (2008). İstanbul İlindeki Beş Yıldızlı Otellerin Örgütsel Sağlık Durumlarının Çalışanların Algıları ile Ölçümüne Yönelik Bir Araştırma, Yönetim Dergisi, 19(60), 61-73.

Eren Gümüştekin, G. ve Öztemiz, A. B.. (2004). Örgütsel Stres Yönetimi ve Uçucu Personel Üzerinde Bir Uygulama, Erciyes Üniversitesi İktisadi ve İdari Bilimler Fakültesi Dergisi, 23, 61-85.

Fisher, R. (2001). Role Stress, The Type a Behaviour Pattern, and External Auditor Job Performance and Satisfaction, Behavioral Research in Accounting, 13(1), 143-170.

Goh, J., Pfeffer, J., and Zenios, S. A. (2015). The Relationship between Workplace Stressors and Mortality and Health Costs in the United States, Management Science, 62(2), 608-628.

Grawitch M. J., Gottschalk M. and Munz, D.C. (2006), The Path to a Healthy Workplace: A Critical Review Linking Healthy Workplace Practices, Employee Well-being, and Organizational Improvements, Consulting Psychology Journal: Practice and Research, 58(3), 129-147.

Greenberg, J. and Baron, R. A. (1995). Behavior in Organizations: Understanding and Managing the Human Side of Work, Prentice-Hall International.

Gül, H. (2007). İş Stresi, Örgütsel Sağlık ve Performans Arasındaki İlişkiler: Bir Alan Araştırması, Karamanoğlu Mehmetbey Üniversitesi Sosyal ve Ekonomik Araştırmalar Dergisi, 2, 318-332.

Güllü, S., (2018). Lider Üye Etkileşiminin Çalışma Yaşam Kalitesi ile Üretkenlik Karşıtı İş Davranışları Üzerine Etkisinde Örgüt Sağlığının Aracılık Rolü: Spor İşletmeleri Örneği, Doktora Tezi, İstanbul Üniversitesi Sağlık Bilimleri Enstitüsü.

Hassard, J., Teoh, K. R. H., Visockaite, G., Dewe, P. and Cox, T. (2017). The Cost of Workrelated Stress to Society: A Systematic Review, Journal of Occupational Health Psychology, 23(1), 1-17.

Hoy, W. K. and Miskel, C. W. (1991). Educational Administration: Theory into Practice, New York, McGraw-Hili.

Hoy, W. K. and Tarter, C. J. (1997). The Road to Open and Healthy Schools: The Handbook for Change, Thousand Oaks, CA: Corwin.

Hoy, W. K., Tarter, C. J. and Bliss, J. (1990). Organizational Climate, School Health, and Student Achievement: A Comparative Analysis, Educational Administration Quarterly, 26, 260- 279.

Hu, H.S. and Cheng, C. (2010). Job Stress, Coping Strategies, and Burnout Among Hotel İndustry Supervisors in Taiwan, The International Journal of Human Resource Management, 21(8), 1337-1350.

Hwang, J., Hyun, S. S. and Park, J. (2013), Segmentation of Hotel Employees by Occupational Stress and Differences in Demographic Characteristics, Asia Pacific Journal of Tourism Research, 18(3), 241-261.

Hwang J., Junghoon, J., Park, S. and Chang, H. ve Samuel S. (2014). The Impact of Occupational Stress on Employee's Turnover Intention in the Luxury Hotel Segment, International Journal of Hospitality and Tourism Administration, 15(1), 60-77.

Kant, R. (2017). Organizational Health of Secondary School Teachers in Relation to Their Adjustment, Education Science and Psychology, 3(45), 63-72.

Kemer, E. ve Aslan, Z. (2017). Örgütsel Adaletin Örgüt Sağllğına Etkisinde Örgütsel Özdeşleşmenin Rolü: Nevşehir İlindeki Konaklama İşletmelerinde Bir Araştırma, İşletme Araştırmaları Dergisi, 9(2), 440-460.

Kılıç, G., Tunç, T., Saraçlı, S. ve Kılıç İ. (2013). Örgütsel Stresin Örgütsel Sessizlik Üzerine Etkisi: Beş Yıldızlı Termal Otel İşletmelerinde Bir Uygulama, İşletme Araştırmaları Dergisi, 5(1), 17-33.

Leka, S., Griffiths, A., Cox, T. and World Health Organization. (2003). Work Organization and Stress: Systematic Problem Approaches for Employers, Manages and Trade Union Representatives, Occupational and Environmental Health Team, Geneva. 
Lo, K. and Lamm, F. (2005). Occupational Stress in the Hospitality-An Employment Relations, New Zealand Journal of Employment Relations, 30(1), 23-47.

Lyden, J. A. and Klingele, W. E. (2000). Supervising Organizational Health, Supervision, 61(12), 3-6.

Magnuson, J. (1990). Stress Management, Journal of Property Management, 55(3), 24-26.

Miles, M. B. (1969). Planned Change and Organizational Health: Figure and Ground, Carver F. D. and Sergiovanni, T. J. (Eds.), Organizations and Human Behavior: Focus on Schools, New York, McGraw Hill.

Nelson, D. L. and Burke, R. J. (2000). Women Executives: Health, Stress, and Success, Academy of Management Executive, 14, 107-121.

Nyakora, M. O., (2016). Literature Review of Organizational Health: A Review of Underlying Factors that Influence Organizational Culture and Climate for Overallhealth and Peak Performance, International Journal of Scientific Research and Innovative Technology, 3(12), 25-33.

Özdamar, K. (2001). Spss ile Biyoistatistik, Eskişehir, Kaan Kitabevi.

Pallesen, E. S. (2007). Work-Related Stress and Health Among Hotel Employees in Malmo, Dissertation, Kristianstad University.

Pordeli, F. and Vazifeh, Z. (2017). Examination of the Impact of Promotion of Organizational Health on Organizational Commitment among Employees of Zabol University of Medical Sciences, Revista QUID (Special Issue), 2444-2455.

Robbins, S.P. (2001). Organizational Behavior, New Jersey, Prentice-Hall, Inc.

Şahin, N., (2007). Personel Güçlendirmenin İş Tatmini ve Örgütsel Bağllılı Üzerine Etkisi: Dört ve Beş Yıldızlı Otel İşletmelerinde Bir Uygulama, Doktora Tezi, Dokuz Eylül Üniversitesi Sosyal Bilimler Enstitüsü.

Sandıkçı, M., Vural, T. ve Zorlu, Ö. (2015). Otel İşletmelerinde Dönüştürücü Liderlik Davranışlarının Örgüt Sağlığı Üzerine Etkileri: Afyonkarahisar İlinde Bir Araştırma, Yönetim Bilimleri Dergisi, 13(25), 161-200.

Sauter, S.L., Lim, S.Y. and Murphy, L.R., (1996), Organizational Health: A New Paradigm for Occupational Stress Research at NIOSH, Japanese Journal of Occupational Mental Health, 4(4), 248-254.

Shi, Y., Sears, L. E., Coberley, C. R., and Pope, J. E. (2013). The Association between Modifiable Well-Being Risks and Productivity, Journal of Occupational and Environmental Medicine, 55(4), 353-364.

Sökmen, A. (2005). Konaklama İşletmeleri Yöneticilerinin Stres Nedenlerinin Belirlenmesinde Cinsiyet Faktörü: Adana'da Ampirik Bir Araştırma, Ekonomik ve Sosyal Araştırmalar Dergisi, 1, 1-27.

Sparks, K. and Cooper, C. (199), Occupational Differences in the Work-Strain Relationship towards the use of Situational Specific Modes, Journal of Occupational and Organizational Psychology, 72, 219-229.

Suiçer, M. (2016). Otantik Liderlik Davranışının Örgüt Sağllğı Üzerindeki Etkisi: Otel İşletmelerinde Bir Uygulama. Yüksek Lisans Tezi, Nevşehir Hacı Bektaş Veli Üniversitesi Sosyal Bilimler Enstitüsü.

Tiyce, M., Hing, N., Cairncross, G., and Breen, H. (2013). Employee Stress and Stressors in Gambling and Hospitality Workplaces, Journal of Human Resources in Hospitality and Tourism,12(2), 126-154.

Tuğal, F.N., Topsakal, Y. ve İplik, E. (2017). Örgütsel Sağlığın Çalışanların İş Tatmini ve Yabancılaşma Düzeyine Etkisinde Örgütsel Adaletin Aracı Rolü, Ordu Üniversitesi Sosyal Bilimler Araştırmaları Dergisi, 7(3), 479488.

Uzun, Ö. ve Yiğit E. (2011). Örgütsel Stres ve Örgütsel Bağlllık İlişkisi Üzerine Orta Kademe Otel Yöneticileri Üzerinde Yapılan Bir Araştırma, Eskişehir Osmangazi Üniversitesi, İktisadi ve İdari Bilimler Dergisi, 6(1), 181-213.

Vural, T., (2013). Otel İşletmelerinde Dönüştürücü Liderlik Davranışlarının Örgüt Sağllğı Üzerine Etkisi: Afyonkarahisar İlinde Bir Araştırma, Yüksek Lisans Tezi, Afyon Kocatepe Üniversitesi Sosyal Bilimler Enstitüsü. 
Wan, P. Y. K. (2013), Work Stress Among Casino Industry Supervisors in Macao Casinos, International Journal of Hospitality and Tourism Administration, 14(2), 179-201.

Yılmaz, A., (2016). Algılanan Örgütsel Destek Ortamında İş Stresi ve İş Yaşam Kalitesinin İş Performansı Üzerine Etkisinin Araştırılması: İstanbul'da Bulunan Beş Yıldızlı Otellerde Çalışan Aşçılar Üzerine Bir Araştırma, Doktora Tezi, İstanbul Üniversitesi, Sosyal Bilimler Enstitüsü.

Yirik, Ş., Ören, D. ve Ekici, R. (2014). Dört ve Beş Yıldızlı Otel İşletmelerinde Çalışan Personelin Örgütsel Stres ve Örgütsel Tükenmişlik Düzeyleri Arasındaki İlişkilerin Demografik Değişkenler Bazında İncelenmesi, Journal of Yasar University, 9(35), 6099-6260.

Yousefi, M., Abdullahm, A.G. and Mohamad, A.R. (2016). Stress in Organization: How to Reduce Job Stress in Workplace, International Journal of Research in Management and Business Studies, 3(2), 31-33.

Zamora, L., (2016). The Impact of Organizational Health on Student Achievement in a High Needs District, Journal of Studies in Education, 6(3), 149-167. 